\title{
The role of vaspin in porcine corpus luteum
}

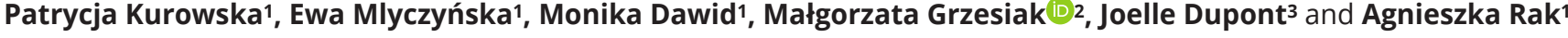 \\ 1Department of Physiology and Toxicology of Reproduction, Jagiellonian University in Krakow, Krakow, Poland \\ 2Department of Endocrinology, Jagiellonian University in Krakow, Krakow, Poland \\ IINRAE, UMR85, Unité Physiologie de la Reproduction et des Comportements, Nouzilly, France
}

Correspondence should be addressed to A Rak: agnieszka.rak@uj.edu.pI

\begin{abstract}
Vaspin, visceral adipose tissue-derived serine protease inhibitor, plays important roles in inflammation, obesity, and glucose metabolism. Our recent research has shown the expression and role of vaspin in the function of ovarian follicles. However, whether vaspin regulates steroidogenesis and luteolysis in the corpus luteum $(\mathrm{CL})$ is still unknown. The aim of this study was first to determine the expression of vaspin and its receptor GRP78 in porcine $\mathrm{CL}$ at the early, middle, and late stages of the luteal phase. Next, we investigated the hormonal regulation of vaspin levels in luteal cells in response to luteinizing hormone (LH), progesterone (P4), and prostaglandin PGE2 and PGF2 $\alpha$. Finally, we determined vaspin's direct impact on luteal cells steroidogenesis, luteolysis and kinases phosphorylation. Our results are the first to show higher vaspin/ GRP78 expression in middle and late vs early stages; immunohistochemistry showed cytoplasmic vaspin/GRP78 localization in small and large luteal cells. In vitro, we found that LH, P4, PGE2, and PGF2 $\alpha$ significantly decreased vaspin levels. Furthermore, vaspin stimulated steroidogenesis by the activation of the GRP78 receptor and protein kinase $A$ (PKA). Also, vaspin increased the ratio of luteotropic PGE2 to luteolytic PGF2 $\alpha$ secretion via GRP78 and mitogen-activated kinase (MAP3/1). Moreover, vaspin, in a dose-dependent manner, decreased GRP78 expression, while it, in a time-dependent manner, increased kinases PKA and MAPK3/1 phosphorylation. Taken together, we found that vaspin/GRP78 expression depends on the luteal phase stage and vaspin affects luteal cells endocrinology, indicating that vaspin is a new regulator of luteal cells steroidogenesis and $\mathrm{CL}$ formation.
\end{abstract}

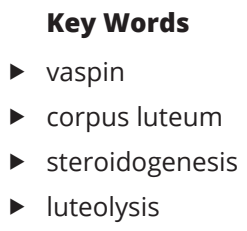

Journal of Endocrinology (2020) 247, 283-294

\section{Introduction}

Visceral adipose tissue-derived serpin - vaspin - is an adipocytokine identified in 2005 from the visceral adipose tissue of Otsuka Long-Evans Tokushima Fatty (OLETF) rat (Hida et al. 2005). Rat, mouse, and human vaspins are made up of 392, 394, and 395 amino acids, respectively; they exhibit approximately 40\% homology with $\alpha 1$-antitrypsin and are related to the serine protease inhibitor family. Previous studies found vaspin in human, mice, bovine, and porcine tissues including adipose tissue, hypothalamus, cerebrospinal fluid, liver, heart, kidney, stomach, skeletal muscles and ovary (Li et al. 2008, Klöting et al. 2011, Lai et al. 2013, Kurowska et al. 2019a). The expression of vaspin in visceral and s.c. adipose tissue has been found to be positively correlated with BMI and body fat content, as well as with an increase in body fat and the deterioration of metabolic disorder (Heiker 2014). Studies have shown that vaspin has an insulin-sensitizing effect, improves glucose tolerance, and has actions in the body connected with obesity development and inflammation (Heiker 2014). Data in the literature show 
that in endothelial cells, vaspin acts as a ligand for the cellsurface anion channel complex heat shock protein family A (Hsp70) member GRP78 receptor (Nakatsuka et al. 2013). Increasing evidence indicates the important role of vaspin in reproductive physiology. Significantly higher serum levels of vaspin have been observed in women than in men (González et al. 2009) and in women with ovarian pathologies, like polycystic ovarian syndrome (PCOS) (Tan et al. 2008). Vaspin expression was detected in the hypothalamus (Klöting et al. 2011) and ovarian follicles, including the granulosa, theca, and oocytes (Kurowska et al. 2019a). Furthermore, vaspin regulates the biology of ovarian follicular cells by activating various signaling pathways, stimulating steroidogenesis via GRP78 and protein kinase A (PKA) (Kurowska et al. 2020), and having anti-apoptotic properties via GRP78 and mitogen-activated kinase (MAP3/1), protein kinase B (AKT), and Janus kinase (STAT3) pathways (Kurowska et al. 2019b). However, vaspin expression and function in corpus luteum (CL) have never been studied in human or animal models.

The CL is a transient endocrine gland formed from ovulated follicles and is also a site of the rapid remodeling, growth, differentiation, and death of cells originating from granulosa, theca, capillaries, and fibroblasts (Arosh et al. 2004). The CL synthesizes progesterone (P4), a steroid hormone essential for pregnancy maintenance and ovarian periodicity, which plays a central role in the regulation of the estrous cycle (Mesen \& Young 2015). Defects in CL function lead to infertility, miscarriages, and ovarian cycle disorders. If the oocyte is not fertilized, the CL regresses and a new cycle begins (Arosh et al. 2004). The lifespan of CL depends on interactions between luteotropic and luteolytic mediators like prostaglandin, which controls the maturation, maintenance, and regression of CL (Arosh et al. 2004). Prostaglandin E2 (PGE2) stimulates $\mathrm{P} 4$ secretion in porcine luteal cells, while the opposite effect has been observed for prostaglandin F2 $\alpha$ (PGF2 $\alpha$ ) (Gregoraszczuk \& Michas 1999). Decreasing P4 level is connected with functional luteolysis, leading to the degeneration of luteal and endothelial cells, which is defined as structural luteolysis (Diaz et al. 2002). Recent studies indicate that important factors connected with the development, lifespan, and regression of CL, include some novel factors such as adiponectin (Maleszka et al. 2014), and apelin (Różycka et al. 2018). Based on these observations, we hypothesized that vaspin, like other described adipokines, may be an important factor in the regulation of porcine luteal physiology: steroid synthesis or luteolysis. Our study is the first report on the expression of the novel adipokine vaspin and its receptor GRP78 in porcine CL and characterization of its direct biological effects on steroidogenesis and luteolysis.

\section{Materials and methods}

\section{Sample collection}

Porcine ovaries were collected from sexually mature Polish Large White pigs (6-8 months old) at different stages of the luteal phase at a local abattoir; therefore, an agreement of ethical commission is not necessary. Sows were sacrificed during slaughter according to European Legislation (EFSA, AHAW/04-027). Ovaries were transported to the laboratory in PBS with an antibiotic-antimycotic solution within 30 min of collection, then CLs were isolated from the ovaries after morphological examination at the early (2-3 days after ovulation, the presence of corpora hemorrhagica), middle (10-12 days after ovulation, the phase when CL activity is the highest in the cycle), and late (14-16 days after ovulation, the phase of luteolysis) stages of the luteal phase (Rytelewska et al. 2020). To determine vaspin/ GRP78 mRNA expression, CLs $(n=10$ animal per stage, $1 \mathrm{CL}$ from 1 animal, so the total number of animals was 30) were immediately frozen in liquid nitrogen and stored at $-70^{\circ} \mathrm{C}$. To determine vaspin/GRP78 protein expression, CLs ( $n=10$ /animal per stage) were homogenized twice in an ice-cold lysis buffer (50 mM Tris- $\mathrm{HCl}(\mathrm{pH} 7.5)$ containing $100 \mathrm{mM} \mathrm{NaCl}, 0.5 \%$ sodium deoxycholate $(\mathrm{w} / \mathrm{v}), 0.5 \% \mathrm{NP}-40(\mathrm{v} / \mathrm{v}), 0.5 \%$ SDS $(\mathrm{w} / \mathrm{v})$, and protease inhibitor). Lysates were cleared by centrifugation $(15,000$ $\boldsymbol{g}$ at $4^{\circ} \mathrm{C}$ for $30 \mathrm{~min}$ ); subsequently, protein levels were determined using the Bradford method. To determine vaspin/GRP78 immunolocalization, $\mathrm{CL}$ at the middle luteal stage ( $n=4$, from four animals) were fixed in $4 \%$ $(\mathrm{v} / \mathrm{v})$ paraformaldehyde and subsequently dehydrated in an increasing gradient of ethanol and embedded in Paraplast.

\section{Cell culture and experimental procedure}

Based on results from vaspin/GPR78 expression in the in vitro experiments, we used only CL from the middle luteal stage of the estrous cycle. Luteal cell cultures were prepared according to Gregoraszczuk (1983). After isolation, luteal cells were resuspended in M199 with 10\% FBS $(\mathrm{v} / \mathrm{v})$. The viability of cells was determined using a Trypan blue exclusion test (95\%). Finally, the cells were subsequently plated in 96-well tissue culture plates at a 
concentration of $6 \times 10^{4}$ cells/well for $24 \mathrm{~h}$. All cultures were maintained at $37^{\circ} \mathrm{C}$ in a humidified atmosphere of $5 \% \mathrm{CO}_{2} / 95 \% \mathrm{O}_{2}$

To determine the effect of regulators on vaspin levels, following plating, media were removed and subsequently, luteal cells were incubated for $24 \mathrm{~h}$ in M199 with 1\% FBS (v/v) as control or containing LH (50-150 ng/mL), P4 $\left(10^{-8}-10^{-6}\right) \mathrm{M}$, and prostaglandin PGE2 and PGF2 $\alpha$ (10-250 ng/mL). Doses of hormones were based on Kurowska et al. (2019a). After incubation, the culture medium was stored at $-20^{\circ} \mathrm{C}$ to measure vaspin concentrations, while cells were washed in PBS and then boiled in Laemmli buffer for $4 \mathrm{~min}$ and finally stored at $-20^{\circ} \mathrm{C}$ to analyze vaspin protein expression. In this experiment we used five ovaries from five pigs and in vitro culture of luteal cells was repeated four times $(n=4)$ (each treatment in five wells); so the total number of animals was 20 .

To investigate vaspin's effect on steroidogenesis, prostaglandin synthesis, and GRP78 expression, luteal cells were incubated for $24 \mathrm{~h}$ in M199 with 1\% FBS (v/v) as a control or with vaspin at $0.01-100 \mathrm{ng} / \mathrm{mL}$ added alone or with LH (100 ng/mL). Doses of hormones were chosen based on Kurowska et al. (2020). After incubation, the culture medium was stored at $-20^{\circ} \mathrm{C}$ for the quantification of P4, E2, PGE2, and PGF2 $\alpha$ concentrations, while cells were washed in PBS and then boiled in Laemmli buffer for $4 \mathrm{~min}$ and finally stored at $-20^{\circ} \mathrm{C}$ to assess the protein expression of STAR, CYP11A1, HSD3B, CYP19A1, PTGER1, PTGFR, and GRP78. In this experiment we used five ovaries from five pigs and in vitro culture of luteal cells was repeated four times $(n=4)$ (each treatment in five wells); so the total number of animals was 20 .

To study vaspin's effect on kinase phosphorylation, luteal cells were incubated in M199 with 1\% FBS (v/v) as a control or with vaspin $(1 \mathrm{ng} / \mathrm{mL})$ for $1,5,15,30,45$, and 60 min and then cells were washed in PBS and then boiled in Laemmli buffer for $4 \mathrm{~min}$ and finally stored at $-20^{\circ} \mathrm{C}$ to evaluate pMAP3/1, MAP3/1, pPKA, PKA, pSTAT3, and STAT3 protein expression. In this experiment, we used four ovaries from four pigs and in vitro culture of luteal cells was repeated four times $(n=4)$ (each treatment in five wells); so the total number of animals was 16 .

The GRP78 expression was decreased using a siRNA approach as previously described by Park et al. and validated in our laboratory using follicular cells (Kurowska et al. 2019b, 2020). To validate the GRP78 siRNA, luteal cells were incubated for $24 \mathrm{~h}$ in M199 without FBS, then the cells were cultured with GRP78 siRNA ( 1 or $2 \mathrm{nM}$ ) as follows (Park et al. 2017); the sequences of siRNA were based on Kurowska et al. (2019b, 2020). After culturing, cells were stored at $-20^{\circ} \mathrm{C}$ to analyze GRP78 protein expression. In this experiment, we used two ovaries from two pigs and in vitro culture of luteal cells was repeated four times $(n=4)$ (each treatment in five wells); so the total number of animals was 8 .

To investigate whether $\mathrm{P} 4$ and prostaglandin secretion depend on GRP78 or kinase activation, luteal cells were incubated in M199 without FBS for $24 \mathrm{~h}$. After starvation, they were pre-treated with GRP78 siRNA ( $2 \mathrm{nM})$ for $24 \mathrm{~h}$ or pre-treated for $1 \mathrm{~h}$ with MAP3/1 inhibitor PD09859 $(50 \mu \mathrm{M})$ or PKA inhibitor KT5720 (50 ng/mL). Finally, vaspin at $1 \mathrm{ng} / \mathrm{mL}$ was added for the following $24 \mathrm{~h}$ and then the culture medium was stored at $-20^{\circ} \mathrm{C}$ to measure P4, and prostaglandin secretion. In this experiment, we used four ovaries from four pigs and in vitro culture of luteal cells was repeated four times $(n=4)$ (each treatment in five wells); so the total number of animals was 16 . The total number of pigs in all experiments was 80 .

\section{RNA isolation and real-time PCR}

Total RNA was isolated using TRIzol reagent according to the manufacturer's protocol (Reverchon et al. 2014). RT and mRNA expression measured by real-time PCR were done as described previously (Kurowska et al. 2019a). The quantities of housekeeping genes, PPIA (cyclophilin $\mathrm{A})$, and $G A P D H$ were determined and normalized according to rules described by Vandesompele et al. (2002). The primers sequence was as follows: vaspin (forward 5'-GCTGTGAGTCGTGACCAAGT-3' and reverse 5'-CACAGAGATGCTCCAAGGG-3'), GRP78 (forward 5'-ATCGAGTTGGCTTTCCGTGT-3' and reverse 5'-CCAGTCAGTCAGTCAGCAGG-3'), PPIA (forward 5'-GCATACAGGTCCTGGCATCT-3' and reverse 5'-TGTCCACATGCAGCAATGGT-3'), and GAPDH (forward 5'-GCACCGTCAAGGCTGAGAAC-3' and reverse 5'-ATGGTGGTGAAGACGCCAGT-3'). RNA and cDNA quantities were evaluated by measuring absorbance at 260 and $280 \mathrm{~nm}$ using spectrophotometry with efficiency between 1.8 and 2.0 .

\section{Western blot}

Tissue preparation, lysis, Western blotting, and quantification were performed as previously described (Rak et al. 2015). For each sample, 30-50 $\mu$ g of protein were subjected to Western blot. Primary and secondary antibodies are described in Table 1. An anti-actin antibody was used as the loading control. Signals were detected by 
Table 1 Antibodies used to Western blot.

\begin{tabular}{|c|c|c|c|}
\hline Antibody & $\begin{array}{l}\text { Host } \\
\text { species }\end{array}$ & Dilution & Vendor \\
\hline Vaspin & Rabbit & $1: 1000$ & $\begin{array}{l}\text { ThermoFisher Scientific } \\
\text { product no. PA1-30989 }\end{array}$ \\
\hline GRP78 & Rabbit & $1: 700$ & $\begin{array}{l}\text { ThermoFisher Scientific } \\
\text { product no. PA5-19503 }\end{array}$ \\
\hline STAR & Rabbit & $1: 500$ & $\begin{array}{l}\text { Abcam } \\
\text { product no. ab233427 }\end{array}$ \\
\hline CYP11A1 & Goat & $1: 200$ & $\begin{array}{l}\text { Santa Cruz Biotechnology } \\
\text { product no. sc- } 18040\end{array}$ \\
\hline HSD3B & Mouse & $1: 1000$ & $\begin{array}{l}\text { Abcam } \\
\text { product no. ab75710 }\end{array}$ \\
\hline CYP19A1 & Rabbit & $1: 200$ & $\begin{array}{l}\text { ThermoFisher Scientific } \\
\text { product no. PA1-21398 }\end{array}$ \\
\hline PTGER1 & Rabbit & $1: 200$ & $\begin{array}{l}\text { Abcam } \\
\text { product no. } 183073\end{array}$ \\
\hline PTGFR & Rabbit & $1: 200$ & $\begin{array}{l}\text { ThermoFisher Scientific } \\
\text { product no. PA5-70674 }\end{array}$ \\
\hline pMAP3/1 & Rabbit & $1: 1000$ & $\begin{array}{l}\text { Cell Signaling Technology } \\
\text { product no. \#9101S }\end{array}$ \\
\hline MAP3/1 & Rabbit & $1: 1000$ & $\begin{array}{l}\text { Cell Signaling Technology } \\
\text { product no. \#9102S }\end{array}$ \\
\hline pPKA & Rabbit & $1: 1000$ & $\begin{array}{l}\text { Abcam } \\
\text { product no. ab5815 }\end{array}$ \\
\hline PKA & Rabbit & $1: 500$ & $\begin{array}{l}\text { Abcam } \\
\text { product no. ab187515 }\end{array}$ \\
\hline pSTAT3 & Rabbit & $1: 1000$ & $\begin{array}{l}\text { Cell Signaling Technology } \\
\text { product no. \#9131S }\end{array}$ \\
\hline STAT3 & Rabbit & $1: 2000$ & $\begin{array}{l}\text { Cell Signaling Technology } \\
\text { product no. \#4904S }\end{array}$ \\
\hline Actin & Mouse & $1: 5000$ & $\begin{array}{l}\text { Sigma-Aldrich } \\
\text { product no. A5316 }\end{array}$ \\
\hline Anti-mouse & Horse & $1: 1000$ & $\begin{array}{l}\text { Cell Signaling Technology } \\
\text { product no. \#7076 }\end{array}$ \\
\hline Anti-rabbit & Goat & $1: 1000$ & $\begin{array}{l}\text { Cell Signaling Technology } \\
\text { product no. \#7074 }\end{array}$ \\
\hline Anti-goat & Mouse & $1: 1000$ & $\begin{array}{l}\text { Santa Cruz Biotechnology } \\
\text { product no. sc } 2354\end{array}$ \\
\hline
\end{tabular}

chemiluminescence using WesternBright Quantum HRP substrate and visualized using the Chemidoc XRS + System (BioRad). All visible bands were quantified using a densitometer and ImageJ software (US NIH).

\section{Immunohistochemistry}

Paraformaldehyde-fixed paraffin-embedded CL sections $(5 \mu \mathrm{m})$ were processed by immunohistochemical analysis. Protein block was performed with 5\% goat serum for $30 \mathrm{~min}$ in order to block nonspecific binding agents, then incubated with the primary antibodies (Table 1) antivaspin (1:100) or anti-GPR78 (1:50). Next, biotinylated goat anti-rabbit IgG (1:300), avidin-biotin-peroxidase complex and 3,3'-diaminobenzidine (Sigma-Aldrich) as chromogen antibodies (1: 400) and avidin-biotinylated horseradish peroxidase complex (1:100) were applied.
Sections were then counterstained with hematoxylin, dehydrated, and mounted in DPX (Sigma-Aldrich). For negative control reaction, sections were incubated with non-immune rabbit IgG instead of primary antibodies and processed as above. Selected sections were photographed using a Nikon Eclipse Ni-U microscope and a Nikon Digital DS-Fi1-U3 camera (Nikon) with corresponding software. Objective Plan Apo $\lambda(20 \times / 0.75)$.

\section{Enzyme-linked immunosorbent assay (ELISA)}

Porcine vaspin ELISA kit (product no. MBS267502, MyBioSource, USA), P4 and E2 ELISA kits (product no. EIA-1561, EIA-2693, DRG Instruments GmbH, Germany), and PGE2 and PGF2 $\alpha$ ELISA kits (product no. ADI-900-001, ADI-900-069, Enzo Life Sciences, USA) were used according to the manufacturers' protocols. The sensitivity was $0.05 \mathrm{ng} / \mathrm{mL}$ for vaspin, $0.045 \mathrm{ng} / \mathrm{mL}$ for P4, $9.714 \mathrm{pg} / \mathrm{mL}$ for E2, $13.400 \mathrm{pg} / \mathrm{mL}$ for PGE2 and $6.710 \mathrm{pg} / \mathrm{mL}$ for PGF2 $\alpha$. The inter- and intra-experimental coefficients of variation were $<12$ and $<8 \%$, respectively, for vaspin, $<9.96$ and $<6.99 \%$ for $\mathrm{P} 4,<9.39$ and $<6.81 \%$ for E2, $<3.90$ and $<17.50 \%$ for PGE2 and $<5.50$ and $<6.80 \%$ for PGF2 $\alpha$. Absorbance was measured at the $405 \mathrm{~nm}$ wavelength using an ELx808 ELISA microplate reader and KC JUNIOR software (BioTek Instruments).

\section{Statistical analysis}

Statistical data are presented as the means Is.E.M. Distribution of normality was checked by the ShapiroWilk test. Statistical analysis was carried out using one-way or two-way ANOVA, followed by the Tukey test (PRISM software version 5; GraphPad). Statistical significance is indicated by different letters $(P<0.05)$. All outliers data have been included in statistical analysis and presented on graphs.

\section{Results}

\section{Expression of vaspin and GRP78 in CLs at different stages of the luteal phase}

Vaspin and Grp78 mRNAs are expressed in porcine CL during the estrous cycle (Fig. 1A), suggesting that vaspin may play direct or indirect roles in the regulation of CL development. We observed that both the mRNA and protein expression of vaspin/GRP78 depend on the stage of the luteal phase: significantly higher levels were observed 
A

\begin{tabular}{lll}
\hline & $\begin{array}{l}\text { vaspin/ } \\
\text { geometric mean }\end{array}$ & $\begin{array}{l}\text { GRP78/ } \\
\text { geometric mean }\end{array}$ \\
CL1 & $0.006 \pm 0.001^{\mathrm{a}}$ & $3.055 \pm 0.384^{\mathrm{c}}$ \\
CL2 & $0.019 \pm 0.005^{\mathrm{b}}$ & $4.992 \pm 0.589^{\mathrm{d}}$ \\
CL3 & $0.019 \pm 0.003^{\mathrm{b}}$ & $4.622 \pm 0.576^{\mathrm{d}}$
\end{tabular}

B

CL1 CL2 CL3

CL1 CL2 CL3
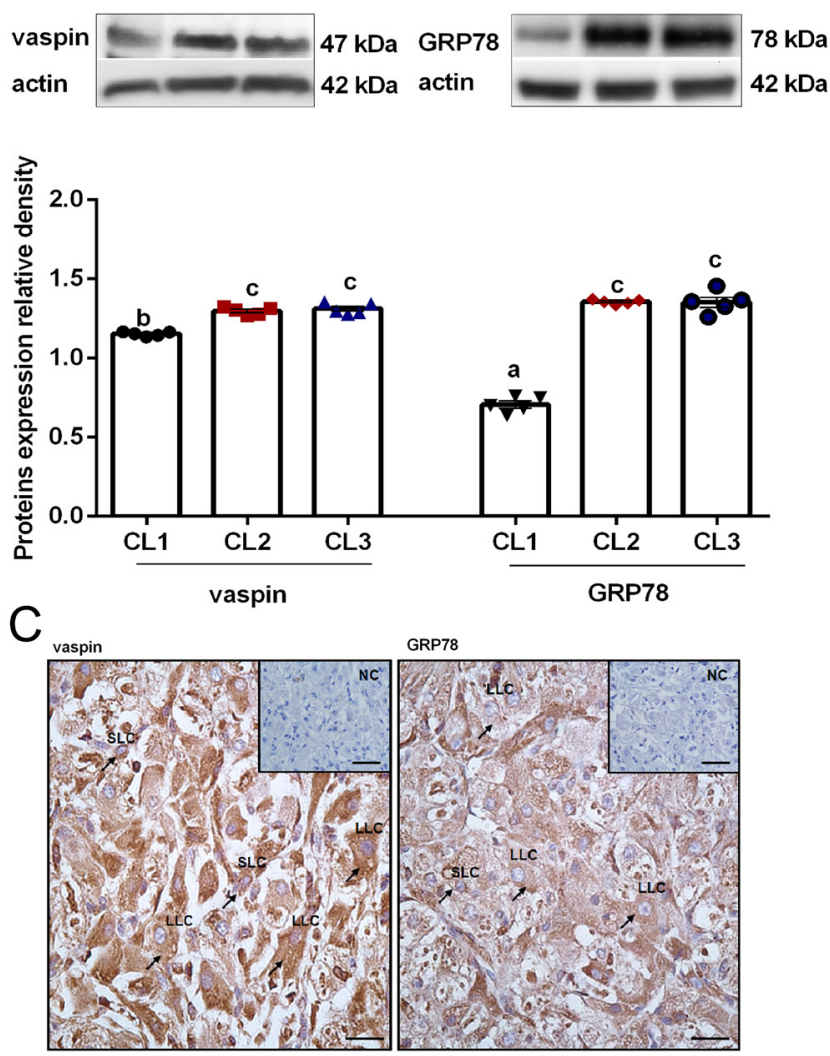

Figure 1

Vaspin and GRP78 mRNA (A) and protein (B) expression in porcine CLs at different stages of the luteal phase $(n=10)$. Positive vaspin/GRP78 staining were observed in the cytoplasm of large (arrows) and small (open arrows) luteal cells (C), bar $=50 \mu \mathrm{m}$. Genes expression levels were normalized to PPIA and GAPDH geometric mean. Data are plotted as the means \pm S.E.M. Statistical analysis was carried out using one-way ANOVA, followed by Tukey's test. Different letters indicate differences between groups $(P<0.05)$. CL1, early; $C L 2$, middle, $C L 3$, late luteal phase. A full color version of this figure is available at https://doi.org/10.1530/JOE-20-0332.

in the middle and late compared to the early stage (Fig. 1A and $\mathrm{B}, n=10$ ). Immunohistochemistry staining showed that vaspin and GRP78 were found in the cytoplasm of large (arrows) and small (open arrows) luteal cells (Fig. $1 \mathrm{C}, n=4)$ indicating that the vaspin/GRP78 signaling may play a role in the functionality of the CL.

\section{Effects of LH, P4, PGE2, and PGF2 $\alpha$ on vaspin levels}

As studied before, some factors, including gonadotropin and steroid hormones, can regulate vaspin expression in
A
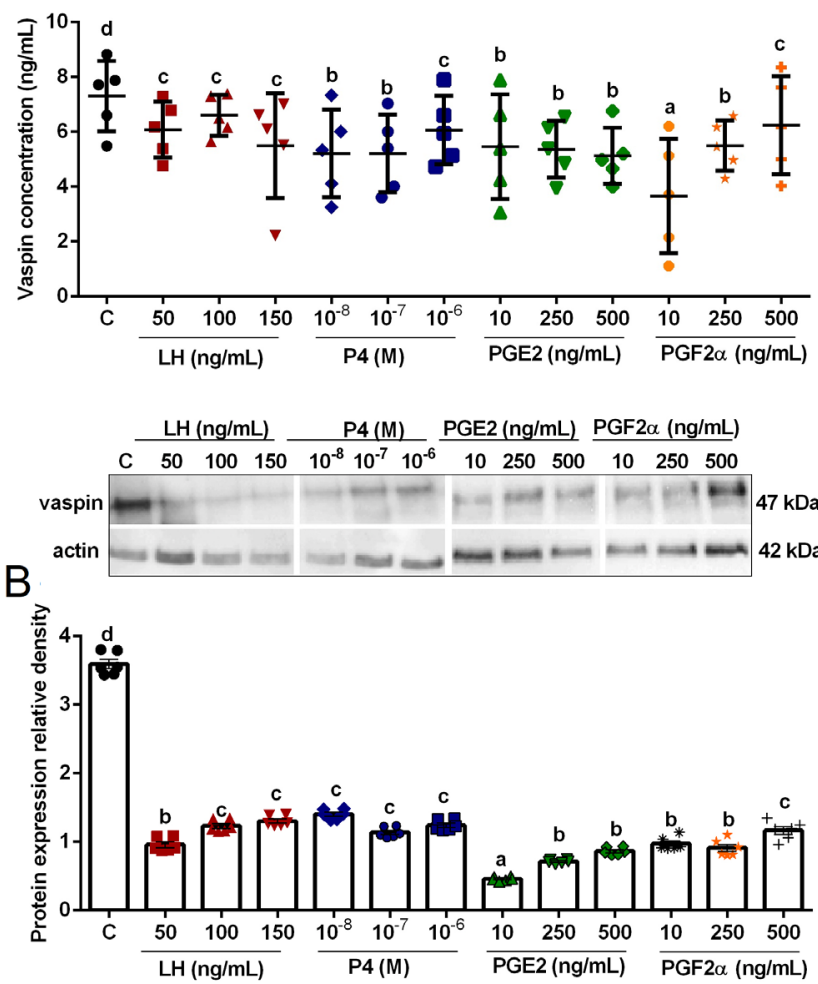

Figure 2

Vaspin secretion (A) and protein expression (B) regulation by $\mathrm{LH}, \mathrm{P} 4$, PGE2, and PGF2 $\alpha$ in luteal cells $(n=4)$. Data are plotted as the means \pm S.E.M. from one representative culture. Statistical analysis was carried out using one-way ANOVA, followed by Tukey's test. Different letters indicate differences between groups $(P<0.05)$. A full color version of this figure is available at https://doi.org/10.1530/JOE-20-0332.

ovarian follicle cells (Kurowska et al. 2019a). In the present studies, we observed a reduction in vaspin secretion from luteal cells by $\mathrm{LH}, \mathrm{P} 4$, and prostaglandins at all investigated doses (Fig. 2A, $n=4$ ). Interestingly, the inhibitory effect of all investigated factors on vaspin expression was also confirmed for protein levels (Fig. 2B, $n=4$ ).

\section{In vitro effect of vaspin on steroidogenesis}

Vaspin is known to modulate steroidogenesis in ovarian follicular cells (Kurowska et al. 2020). Therefore, we demonstrated that vaspin increased steroidogenesis in luteal cells by stimulating steroid hormone secretion and the expression of steroid enzymes. Vaspin at doses of 1,10 , and $100 \mathrm{ng} / \mathrm{mL}$ increased $\mathrm{P} 4$ secretion, while added with LH did not change the stimulatory effect of LH on P4. Furthermore, vaspin, at all investigated doses, increased E2 secretion and decreased the stimulatory effect of $\mathrm{LH}$, but not to the control level (Fig. 3A, n=4). We observed the stimulatory effect of 

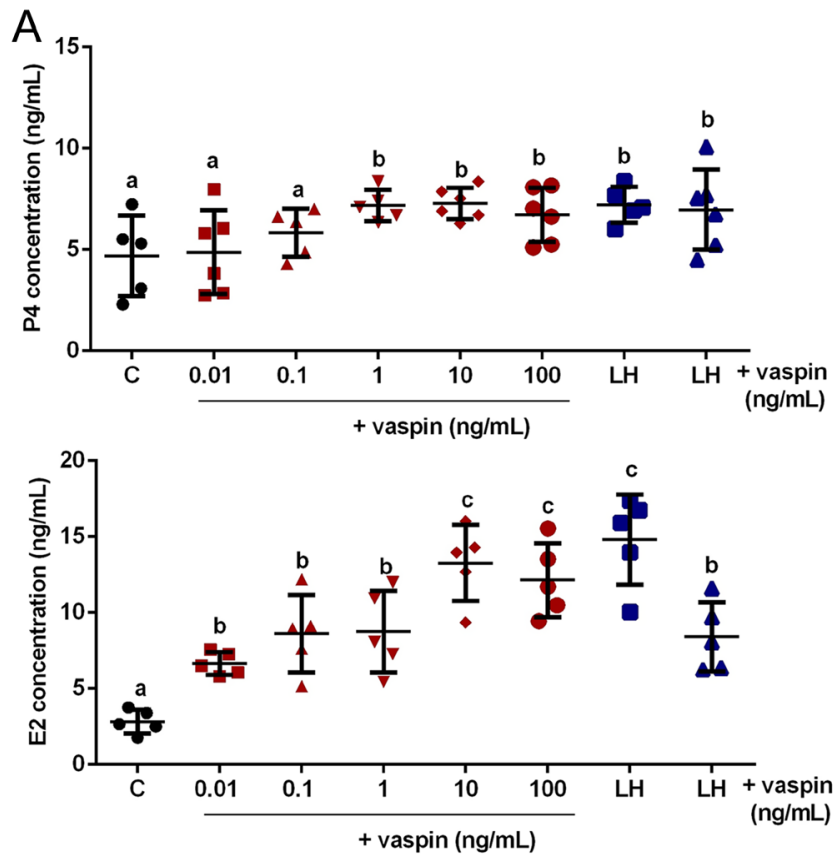

B

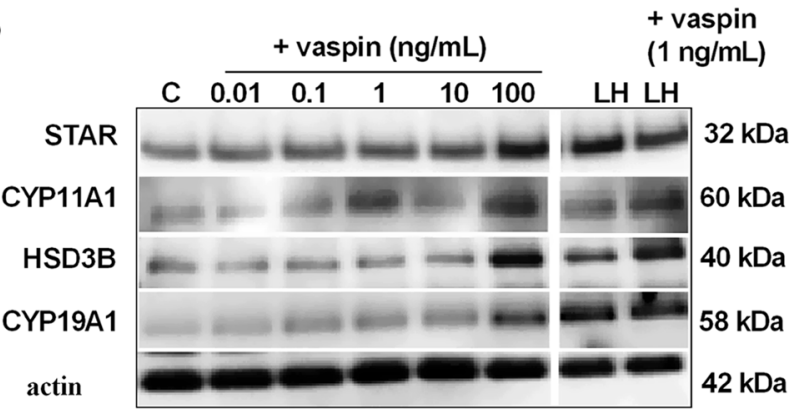

C

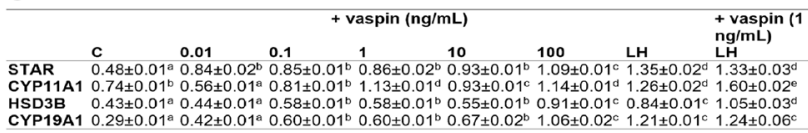

Figure 3

Vaspin's effect on steroids $P 4$ and E2 secretion (A), as well as steroidogenic enzymes protein expression (B) and densitometry analysis (C) in luteal cells $(n=4)$. Data are plotted as the means \pm S.E.M. from one representative culture. Statistical analysis was carried out using one-way ANOVA, followed by Tukey's test. Different letters indicate differences between groups $(P<0.05)$. A full color version of this figure is available at https://doi.org/10.1530/JOE-20-0332.

vaspin at all investigated doses on STAR, at $1-100 \mathrm{ng} / \mathrm{mL}$ on CYP11A1, and at $0.1-100 \mathrm{ng} / \mathrm{mL}$ on HSD3B and CYP19A1 protein expression. Interestingly, we noted that vaspin at $1 \mathrm{ng} / \mathrm{mL}$ increased LH-induced CYP11A1 and HSD3B expression (Fig. 3B and C, $n=4$ ). These results indicate that vaspin is a regulator of luteal cells steroid synthesis.
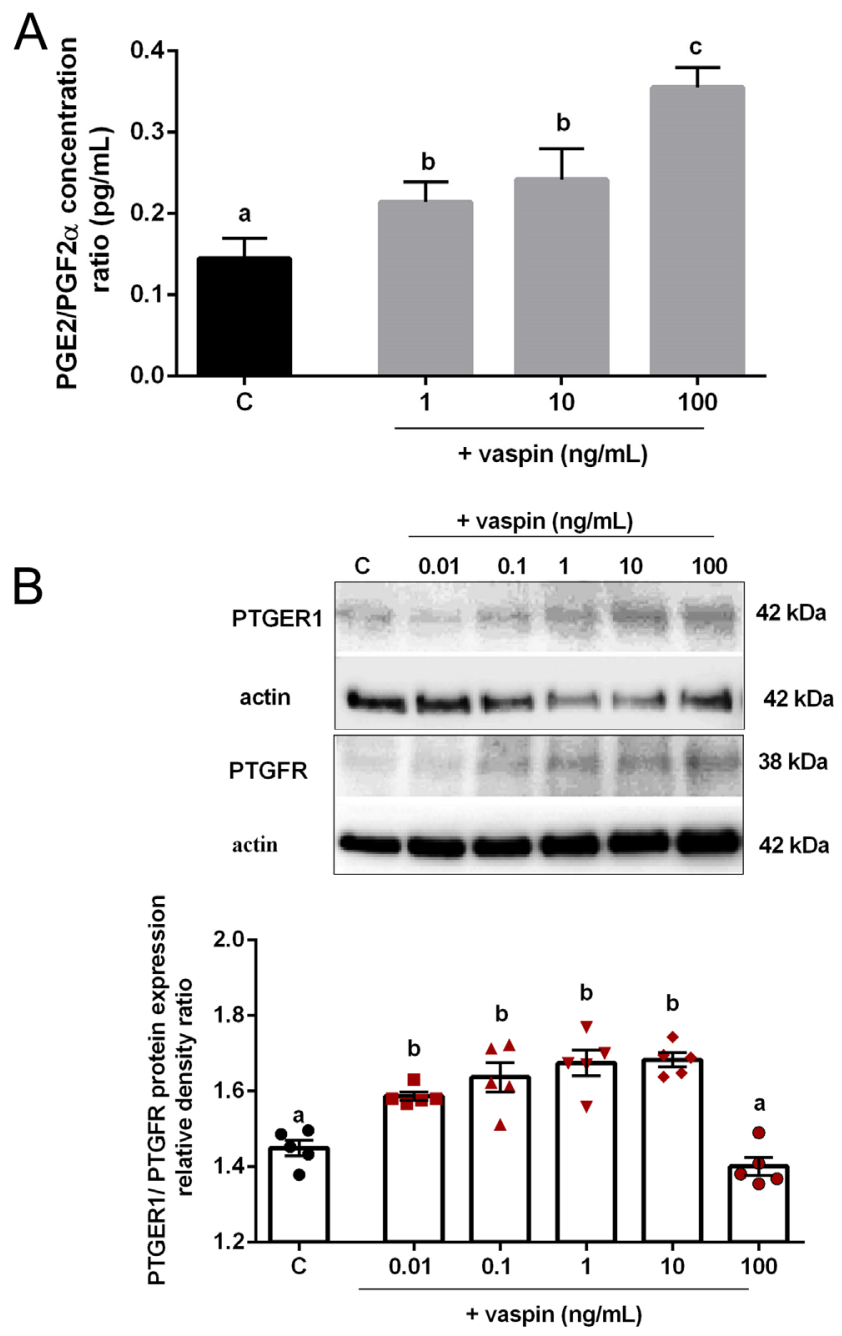

Figure 4

Vaspin's effect on prostaglandin secretion (A) and receptors PTGER1/PTGFR protein expression (B) in luteal cells $(n=4)$. Data are plotted as the means \pm S.E.M. from one representative culture. Statistical analysis was carried out using one-way ANOVA, followed by Tukey's test. Different letters indicate differences between groups $(P<0.05)$. A full color version of this figure is available at https://doi.org/10.1530/JOE-20-0332.

\section{In vitro effect of vaspin on prostaglandin secretion and PTGER1/PTGFR receptors expression}

Prostaglandins balance luteotropic and luteolytic properties in the porcine luteal cells (Waclawik 2011). Hence, we documented that vaspin at doses of 1,10 , and $100 \mathrm{ng} / \mathrm{mL}$ significantly increased the ratio of luteotropic PGE2 to luteolytic PGF2 $\alpha$ secretion (Fig. $4 \mathrm{~A}, n=4$ ). Likewise, we noted that vaspin at doses of $0.01-10 \mathrm{ng} / \mathrm{mL}$ increased the ratio of protein expression of receptor PTGER1 to PTGFR (Fig. 4B, $n=4$ ), suggesting that vaspin plays an important role in CL luteolysis. 
A

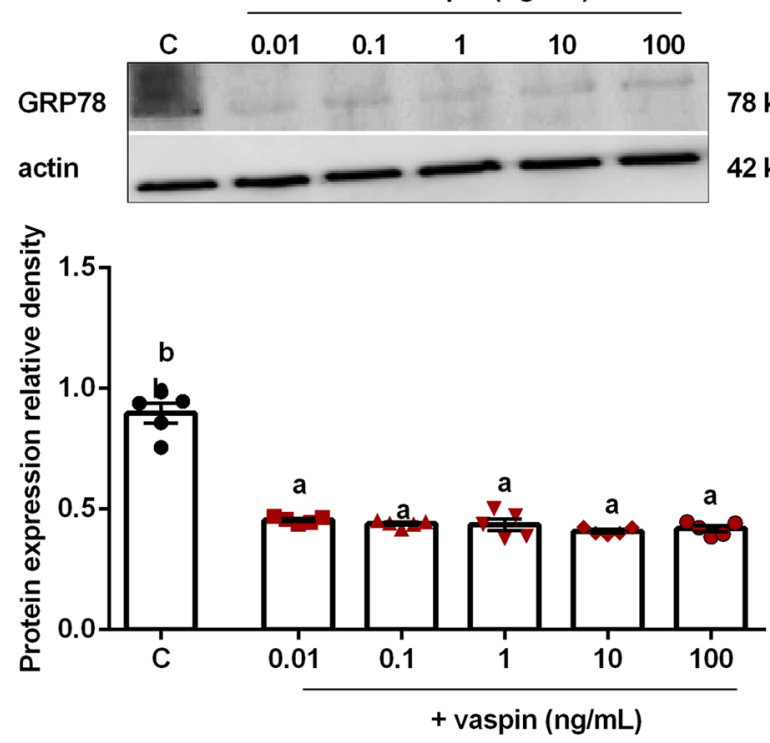

B
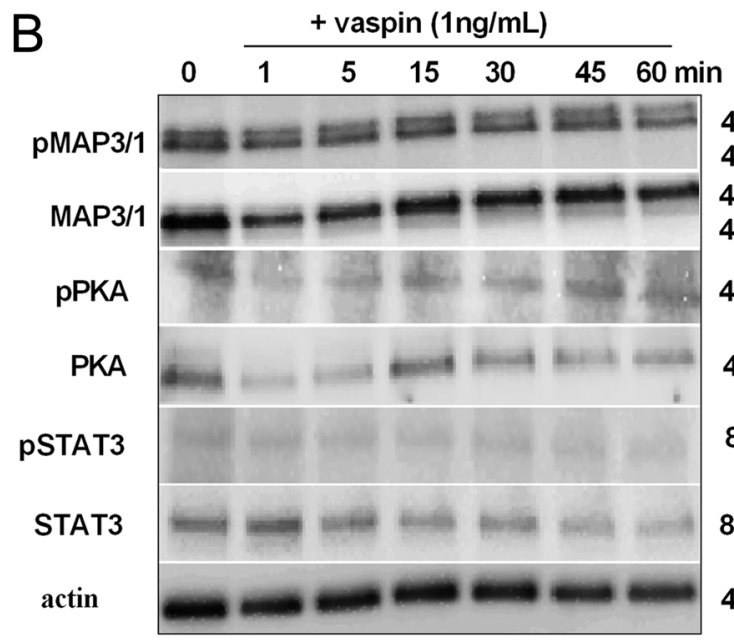

$44 \mathrm{kDa}$

$42 \mathrm{kDa}$

$44 \mathrm{kDa}$

$42 \mathrm{kDa}$

$43 \mathrm{kDa}$

$43 \mathrm{kDa}$

$86 \mathrm{kDa}$

$86 \mathrm{kDa}$

$42 \mathrm{kDa}$

C

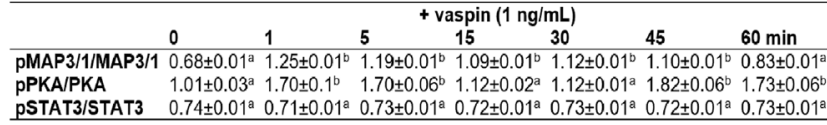

\section{Figure 5}

Vaspin's effect on GRP78 expression (A), kinases phosphorylation (B) and densitometry analysis (C). Data are plotted as the means \pm S.E.M. from one representative culture. Statistical analysis was carried out using one-way ANOVA, followed by Tukey's test. Different letters indicate differences between groups $(P<0.05)$. A full color version of this figure is available at https://doi.org/10.1530/JOE-20-0332.

\section{Involvement of GRP78 and kinase pathways in} vaspin's action on P4 and prostaglandin secretion

We found that vaspin, at all investigated doses, significantly decreased GRP78 protein expression (Fig. 5A, $n=4$ ).
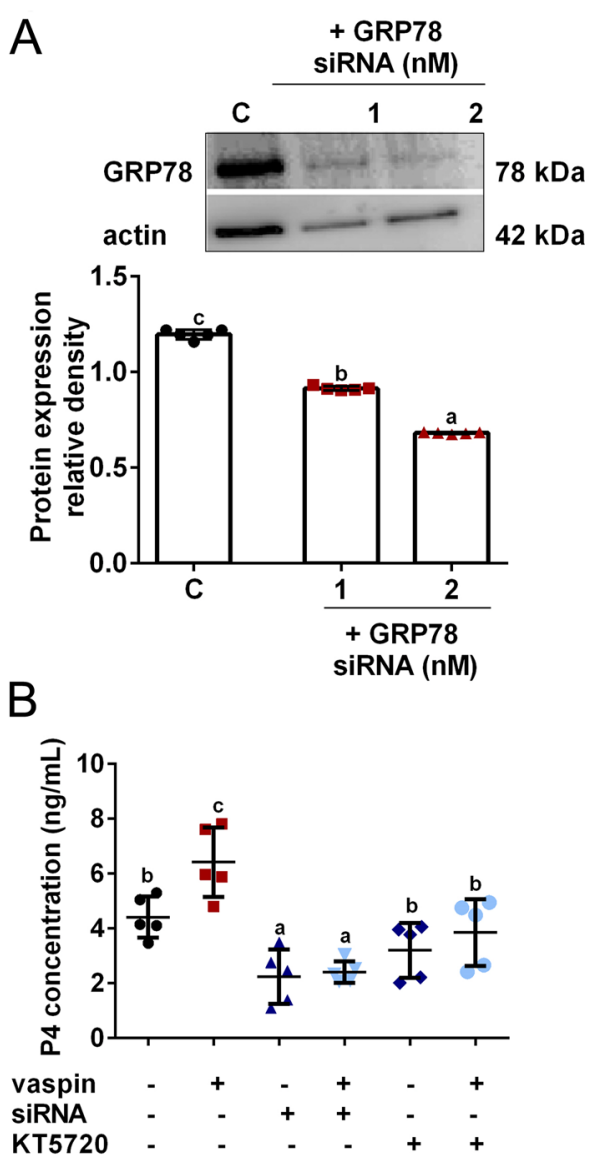

$\mathrm{C}$

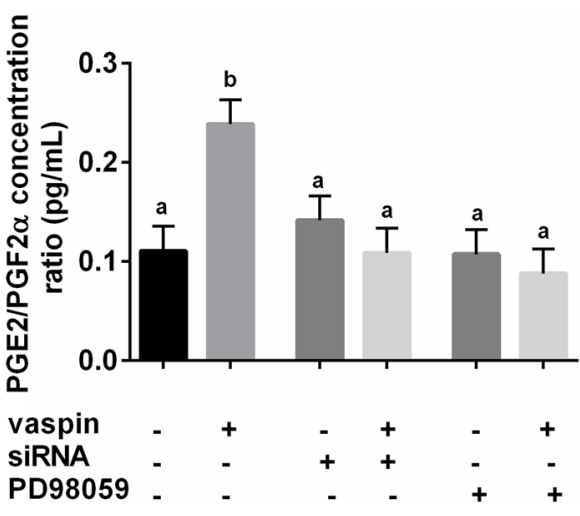

Figure 6

The molecular mechanism of vaspin effect on P4 (B) and prostaglandin secretion (C) by luteal cells $(n=4)$. GRP78 siRNA (A). Data are plotted as the means \pm S.E.M. from one representative culture. Statistical analysis was carried out using one-way ANOVA, followed by Tukey's test. Different letters indicate differences between groups $(P<0.05)$. A full color version of this figure is available at https://doi.org/10.1530/JOE-20-0332.

However, vaspin at a dose of $1 \mathrm{ng} / \mathrm{mL}$, depending on the time of the incubation, increased phosphorylation of MAP3/1 kinase after 1, 5, 15, 30, and 45 min and PKA kinase after 5, 15, 45, and 60 min, while no effect on STAT3 kinase phosphorylation was observed (Fig. $5 \mathrm{~B}$ and C, $n=4$ ). 


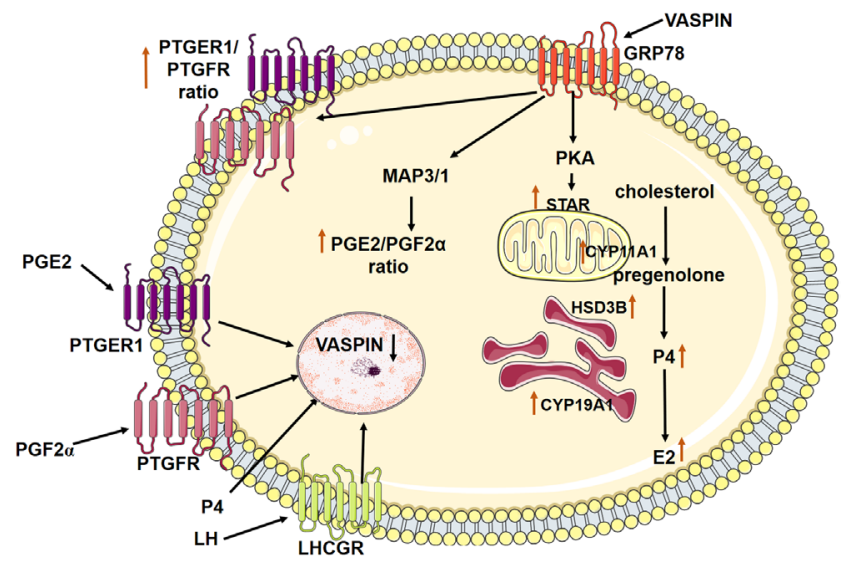

Figure 7

Summary of vaspin's expression, regulation and direct action on biological effects on steroidogenesis and luteolysis in the luteal cells. A full color version of this figure is available at https://doi.org/10.1530/ JOE-20-0332.

To validate the siRNA silencing method, we noted that 1 and $2 \mathrm{nM}$ of GRP78 siRNA decreased GRP78 protein expression (Fig. 6A, $n=4$ ). Consequently, to investigate the molecular mechanism of observed changes in luteal cells, we examined the roles of the GRP78 receptor and the kinases MAP3/1 and PKA in vaspin-mediated P4 and prostaglandin secretion. We observed that simultaneous treatment with GRP78 siRNA $(2 \mathrm{nM})$ or KT5720 $(50 \mathrm{ng} / \mathrm{mL})$ added with vaspin $(1 \mathrm{ng} / \mathrm{mL})$ reversed the stimulatory effect of vaspin on P4 secretion (Fig. 6B, $n=4$ ). Next, treatment with GRP78 siRNA or PD098059 $(50 \mu \mathrm{M})$ added with vaspin reversed the stimulatory effect on the ratio of PGE2/PGF2 $\alpha$ secretion (Fig. 6C, $n=4$ ). Furthermore, we noted that GRP78 siRNA and each inhibitor added alone had no effect on $\mathrm{P} 4$ or prostaglandin secretion.

\section{Discussion}

In the present study, we found, for the first time, that the expression of vaspin and those of GRP78 were significantly different in porcine CL at different stages of the luteal phase. We observed that the expression of vaspin in luteal cells is regulated by several factors like LH, P4, and prostaglandin PGE2 and PGF2 $\alpha$ (Fig. 7). Furthermore, vaspin was shown to affect luteal cells steroid and prostaglandin secretion through GRP78 and PKA and MAPK3/1 activation, respectively, indicating that vaspin is a new regulator of luteal cells function.

We noted that vaspin and its receptor GRP78 are more highly expressed in the CL of the middle and late stages of the luteal phase compared to CL of the early luteal phase. Differences in vaspin levels between individual CL are probably hormonally controlled by LH or steroids secreted by luteal cells, the concentrations of which change during the luteal phases. Lower vaspin levels in the early luteal phase may be connected with ovulation LH peak at the beginning of the luteal phase. We suggest that this factor can negatively regulate vaspin levels at an early stage and can indicate an autocrine interaction; interestingly, when levels of LH start to decrease during the middle and late luteal phases, we noted that vaspin/GRP78 expression in CL of middle and late stages significantly increased. Furthermore, we observed immunolocalization of vaspin/GRP78 in the cytoplasm of small and large luteal cells. Large luteal cells form from granulosa cells after ovulation, while small luteal cells form from theca; our previous paper documented vaspin abundance in the granulosa and theca cells (Kurowska et al. 2019a). Studies have demonstrated the luteal-phase-dependent expression of other adipokines like apelin (Różycka et al. 2018), adiponectin (Maleszka et al. 2014) or chemerin (Rytelewska et al. 2020) in CL.

Our findings demonstrated differences in vaspin/ GRP78 expression in CL at different stages of the luteal phase. In the following experiments, we determined the factors that regulate vaspin expression. We found that $\mathrm{P} 4, \mathrm{LH}$ and prostaglandins are negative regulators of vaspin levels in luteal cells. Hormonal interactions in the hypothalamic-pituitary-ovary axis are essential for proper ovarian physiology, including CL. For example, LH produced by pituitary cells is the parent luteotropic factor in mammals and its pulsative release is necessary for CL development in pigs, cows, and sheep (Stouffer \& Hennebold 2015). P4 is the main hormone released from CL in pregnancy maintenance, while prostaglandins regulate CL formation/regression. PGF2 $\alpha$ is a luteolytic factor, while PGE2 is involved in maintaining the hormonal function of CL (Stouffer \& Hennebold 2015). Our previous findings demonstrated that gonadotropins and steroids stimulated vaspin expression in porcine ovarian follicles by the activation of several kinase pathways (Kurowska et al. 2019a). The different actions of LH and P4 on vaspin levels in luteal and follicular cells can be explained by the type of structure and the phase of the estrus cycle. Likewise, von Loeffelholz et al. (2010) showed that vaspin expression increased in women using contraceptives, indicating the role of steroids in vaspin regulation. Data from Siawrys and Smolińska (2013) document that LH and P4 stimulated leptin expression in https://joe.bioscientifica.com

https://doi.org/10.1530/JOE-20-0332
(C) 2020 Society for Endocrinology Published by Bioscientifica Ltd. Printed in Great Britain 
porcine luteal cells, while in bovine, apelin expression was regulated by PGF2 $\alpha$ (Shirasuna et al. 2008). Interestingly, we observed a stronger inhibitory effect in the vaspin protein expression in luteal cells than vaspin secretion to the culture medium; this effect is probably that some other factors can have an inhibitory effect into luteal cells. For example, leptin mRNA can be regulated negatively by tumor necrosis factor-alpha or interleukin-1beta in human adipocytes (Bruun et al. 2002). In agreement with our observation, Bruun et al. (2002) observed a stronger inhibitory effect on the leptin mRNA level in adipose cells compared to its secretion to the culture medium.

Based on this interesting finding, we have hypothesized that vaspin may be involved in steroid and prostaglandin synthesis. Overall, the expression of both components (ligand and receptor) of the vaspin signaling system allows for analysis of the direct role of vaspin in luteal cells function. The formation, maintenance, regression, and steroidogenesis of CL are among the most significant and closely regulated events in mammalian reproduction. Any dysfunction in luteal steroidogenesis leads to LPD, which results in the failure of embryo implantation and abortion. In general, we observed stimulatory effects of vaspin on steroids P4, E2 secretion, and steroid enzymes protein expression in a dose-dependent manner. We noted a similar observation in follicular cells (Kurowska et al. 2020). Moreover, E2 is a potent tropic hormone that stimulates P4 biosynthesis (Stocco et al. 2007). The middle luteal phase is the most stable phase of mature CL, with full secreting capacity (Stouffer \& Hennebold 2015). Stimulating E2 secretion and decreasing P4 secretion starts at CL from the late stage, where the expression of STAR and HSD3B decrease and CYP19A1 increases; in contrast, CYP11A1 expression is constant (Przygrodzka et al. 2016). Moreover, E2 is essential for CL function, as described in rats, as it participates in the hypertrophy of luteal cells (Stocco et al. 2007). Similarly, in the porcine reproductive tract E2 is a part of embryo signaling systems for CL rescue during pregnancy (Ziecik et al. 2018). Furthermore, in our study, we observed that vaspin combined with LH, decreased $\mathrm{E} 2$ secretion, and caused additional stimulation of CYP11A1 and HSD3B expression; no effects on other study parameters were observed. Similarly, in ovarian follicular cells, vaspin decreased E2 production in culture induced LH (Kurowska et al. 2020). No additional effect of vaspin on P4 and an inhibitory effect on E2 secretion can be a consequence of the negative effect of LH on vaspin expression in the luteal cells. Further investigations are required to understand the molecular mechanisms involved in vaspin interaction with different hormones. However, the differences observed in the present study after LH stimulation between P4 secretion/HSD3B expression or E2/CYP19A1 can be explained by enzyme activity; future studies are needed to discover the activity of the 3BHSD and CYP19A1 enzymes. In rat testes, HSB3B activity can be decreased without affecting enzyme expression (Hierlihy et al. 2006). To confirm our results, previous papers have documented that other adipokines affect luteal steroidogenesis, for example, leptin increased P4 secretion in equine (Galvão et al. 2014) and water buffalo (Kumar et al. 2012). A similar effect of apelin was observed in porcine luteal cells (Różycka et al. 2018), whereas adiponectin decreased P4 secretion (Maleszka et al. 2014).

A balance between luteotropic and luteolytic prostaglandin, which exert their effects throughout membrane receptors PTGER1/2/3 and PTGFR, regulates the lifespan of CL. PGE2 stimulates P4 synthesis and is involved in maintaining CL function; conversely, PGF2 inhibits P4 synthesis and leads to the apoptosis of luteolytic cells (Arosh et al. 2004). PGF2 $\alpha$ causes CL regression by inhibiting cholesterol transport, its conversion to steroid hormones and the stimulation of P4 synthesis by gonadotropin leading to the reduced secretion of P4 and lowered concentrations in the CL and serum. Besides, increases expression of factors associated with PGF2 $\alpha$ synthesis decrease P4 production pathways (Przygrodzka et al. 2016) and PGE2 synthesis in pigs. Data in the literature show that leptin has a luteotropic effect: in equine stimulated PGE2 secretion (Galavao et al. 2014), while in rabbits, it decreased PGF2 $\alpha$ (Sirotkin et al. 2009). Vaspin's effects on prostaglandin synthesis have never been shown in ovaries, but in rat chondrocytes, vaspin combined with interleukin $1 \beta$ increased PGE2 secretion (Bao et al. 2014). In the present study, we documented vaspin's effect on luteal prostaglandin secretion. In our experiments, we chose luteal cells from the middle stage of the luteal phase, because the enzymatic apparatus that mediates luteolysis is responsive to luteolytic stimulus from day 12 of the porcine estrus cycle and allows the possibility of studying CL regression. Interestingly, levels of both prostaglandins in the middle stage are almost constant (Waclawik 2011), which allows directly studying vaspin's effects. We noted that vaspin increased the ratio of PGE2/PGF2 $\alpha$ secretion and PTGER1/PTGFR expression. The importance of the prostaglandin system ratio has been shown by many authors, for example, in cow ovaries: the prostaglandin synthesis ratio PGES to https://joe.bioscientifica.com

https://doi.org/10.1530/JOE-20-0332 (c) 2020 Society for Endocrinology Published by Bioscientifica Ltd. 
PGFS starts to decrease in the late luteal phase leading to luteolysis (Arosh et al. 2004). In porcine CL at the middle stage, changing the PGE2 to PGF2 $\alpha$ ratio from 1:1 to 2:1 protects luteal cells against the inhibitory effect of PGF2 $\alpha$ on P4 secretion (Gregoraszczuk \& Michas 1999).

Finally, to investigate the molecular mechanism of vaspin's role in luteal cells function, we studied the involvement of the GRP78 and kinase phosphorylation. Our study showed that vaspin decreased GRP78 protein expression, which is in good agreement with data we obtained on ovarian follicles (Kurowska et al. 2020). Increasing doses of vaspin lead to the downregulation of the GRP78 receptor in the cell membrane and finally lower protein expression of GRP78 in luteal cells. A similar phenomenon has been observed for leptin and its receptor in mouse liver (Hegyi et al. 2004) and E2 and ER- $\alpha$ in mice mammary glands (Hatsumi \& Yamamuro 2006), indicating the ligand-induced desensitization or internalization of those receptors occurs when receptors have been chronically exposed to an excessive amount of a ligand. To our knowledge, the phosphorylation of kinases is necessary for proper ovarian physiology, including CL. As we described previously MAP3/1, PKA, and STAT3 participate in the regulation of multiple processes, including steroidogenesis, proliferation, and apoptosis (Kurowska et al. 2019b, 2020). Furthermore, differentiation of a luteal phenotype implies numerous changes in the intracellular signaling network; steroid production in bovine luteal cells is mediated by PKA (Jiang et al. 2011), while prostaglandin secretion is regulated by MAP3/1 (Arosh et al. 2004). In this study, we observed vaspin's effects on MAP3/ 1 and PKA phosphorylation, but not on STAT3. Interestingly, in porcine ovarian follicles, we observed the phosphorylation of all investigated kinases by vaspin (Kurowska et al. 2020), which suggests that vaspin's effect depends on the ovarian structure. Using pharmacological inhibitors of kinases and GRP78 silencing, we noted that vaspin stimulated P4 secretion through GRP78 and the activation of PKA, while prostaglandin secretion via GRP78 and MAP3/1. Our results are in agreement with previous work, where the stimulatory effect of vaspin on steroidogenesis in ovarian follicular cells was activated by GRP78 and PKA (Kurowska et al. 2020) or in human placenta cells, apelin affected steroid production by PKA activation (Dawid et al. 2019). Further, in endometrial cancer cells (Gao et al. 2009) and human placenta (Lappas et al. 2005), leptin stimulated PGE2 secretion by MAP3/1 pathways.
In conclusion, vaspin/GRP78 signaling was found in CL at different stages of the estrous cycle. We indicated vaspin increased steroid and prostaglandin synthesis, as well as the phosphorylation of kinases, suggesting that this adipokine can be a new regulator in CL function maintenance. The effect of vaspin/GRP78 on luteal cells steroidogenesis and luteolysis could potentially lead to therapeutic interventions for infertility caused by LPD. However, to confirm the role of vaspin in female fertility, experiments on animal models like vaspin knockout mice should be developed in future studies. Interestingly, data from Cheng et al. (2016) described that female adiponectin null mice displayed impaired folliculogenesis, reduced retrieval of oocytes, disrupted estrous cycle, an elevated number of atretic follicles, which suggested that adipokines are essential for female fertility. Importantly, recent published studies clearly documented the role of vaspin in reproductive pathologies; for example, vaspin could be a potential novel biomarker for the prediction and early diagnosis of PCOS (Tan et al. 2008) or pregnancy pathologies (Mierzyński et al. 2019). Moreover, lower plasma vaspin level is a predictor of successful ovulation in PCOS patients (Dogan et al. 2017).

\section{Declaration of interest}

The authors declare that there is no conflict of the interest that could be perceived as prejudicing the impartiality of the research reported.

\section{Funding}

Supported by the National Science Centre (NSC), Poland (2018/31/N/ NZ9/00959) and partly by DS/MND/WB/IZ/11/2018. Patrycja Kurowska, the author has obtained funding as part of a PhD scholarship program from the NSC (2020/36/T/NZ9/00264).

\section{References}

Arosh JA, Banu SK, Chapdelaine P, Madore E, Sirois J \& Fortier MA 2004 Prostaglandin biosynthesis, transport, and signaling in corpus luteum: a basis for autoregulation of luteal function. Endocrinology 145 2551-2560. (https://doi.org/10.1210/en.2003-1607)

Bao JP, Jiang LF, Li J, Chen WP, Hu PF \& Wu LD 2014 Visceral adipose tissue-derived serine protease inhibitor inhibits interleukin$1 \beta$-induced catabolic and inflammatory responses in murine chondrocytes. Molecular Medicine Reports 10 2191-2197. (https://doi. org/10.3892/mmr.2014.2478)

Bruun JM, Pedersen SB, Kristensen K \& Richelsen B 2002 Effects of proinflammatory cytokines and chemokines on leptin production in human adipose tissue in vitro. Molecular and Cellular Endocrinology 190 91-99. (https://doi.org/10.1016/s0303-7207(02)00007-2)

Cheng L, Shi H, Jin Y, Li X, Pan J, Lai Y, Lin Y, Jin Y, Roy G, Zhao A, et al. 2016 Adiponectin deficiency leads to female subfertility and ovarian https://joe.bioscientifica.com https://doi.org/10.1530/JOE-20-0332 (c) 2020 Society for Endocrinology Published by Bioscientifica Ltd. Printed in Great Britain 
dysfunctions in mice. Endocrinology 157 4875-4887. (https://doi. org/10.1210/en.2015-2080)

Dawid M, Mlyczynska E, Kurowska P, Sierpowski M \& Rak A 2019 Apelin decreased placental hormone secretion by human trophoblast BeWo cells via apelin receptor, protein kinase A and extracellular signalregulated kinases $1 / 2$ activation. Journal of Physiology and Pharmacology 70 95-907. (https://doi.org/10.26402/jpp.2019.6.08)

Diaz FJ, Anderson LE, Wu YL, Rabot A, Tsai SJ \& Wiltbank MC 2002 Regulation of progesterone and prostaglandin F2alpha production in the CL. Molecular and Cellular Endocrinology 191 65-80. (https://doi. org/10.1016/S0303-7207(02)00056-4)

Dogan K, Ekin M, Helvacioğlu Ç \& Yaşar L 2017 Can serum vaspin levels predict clomiphene resistance in infertile women with PCOS? European Journal of Obstetrics, Gynecology, and Reproductive Biology $\mathbf{2 1 7}$ 6-11. (https://doi.org/10.1016/j.ejogrb.2017.08.006)

Galvão A, Tramontano A, Rebordão MR, Amaral A, Bravo PP, Szóstek A, Skarzynski D, Mollo A \& Ferreira-Dias G 2014 Opposing roles of leptin and ghrelin in the equine corpus luteum regulation: an in vitro study. Mediators of Inflammation 2014 682193. (https://doi. org $/ 10.1155 / 2014 / 682193)$

Gao J, Tian J, Lv Y, Shi F, Kong F, Shi H \& Zhao L 2009 Leptin induces functional activation of cyclooxygenase-2 through JAK2/STAT3, MAPK/ERK, and PI3K/AKT pathways in human endometrial cancer cells. Cancer Science 100 389-395. (https://doi.org/10.1111/j.13497006.2008.01053.x)

González CR, Caminos JE, Vázquez MJ, Garcés MF, Cepeda LA, Angel A, González AC, García-Rendueles ME, Sangiao-Alvarellos S, López M, et al. 2009 Regulation of visceral adipose tissue-derived serine protease inhibitor by nutritional status, metformin, gender and pituitary factors in rat white adipose tissue. Journal of Physiology $\mathbf{5 8 7}$ 3741-3750. (https://doi.org/10.1113/jphysiol.2009.172510)

Gregoraszczuk E 1983 Steroid hormone release in cultures of pig corpus luteum and granulosa cells: effect of LH, hCG, PRL and estradiol. Endocrinologia Experimentalis 17 59-68.

Gregoraszczuk EL \& Michas N 1999 Progesterone and estradiol secretion by porcine luteal cells is influenced by individual and combined treatment with prostaglandins E2 and F2alpha throughout the estrus cycle. Prostaglandins and Other Lipid Mediators 57 231-241. (https:// doi.org/10.1016/s0090-6980(99)00009-x)

Hatsumi T \& Yamamuro Y 2006 Downregulation of estrogen receptor gene expression by exogenous 17beta-estradiol in the mammary glands of lactating mice. Experimental Biology and Medicine 231 311-316. (https://doi.org/10.1177/153537020623100311)

Hegyi K, Fülöp KA, Kovács KJ, Falus A \& Tóth S 2004 High leptin level is accompanied with decreased long leptin receptor transcript in histamine deficient transgenic mice. Immunology Letters 92 193-197. (https://doi.org/10.1016/j.imlet.2003.11.029)

Heiker JT 2014 Vaspin (serpinA12) in obesity, insulin resistance, and inflammation. Journal of Peptide Science 20 299-306. (https://doi. org/10.1002/psc.2621)

Hida K, Wada J, Eguchi J, Zhang H, Baba M, Seida A, Hashimoto I, Okada T, Yasuhara A, Nakatsuka A, et al. 2005 Visceral adipose tissue-derived serine protease inhibitor: a unique insulin-sensitizing adipocytokine in obesity. PNAS 102 10610-10615. (https://doi. org/10.1073/pnas.0504703102)

Hierlihy AM, Cooke GM, Curran IH, Mehta R, Karamanos L \& Price CA 2006 Effects of ciprofibrate on testicular and adrenal steroidogenic enzymes in the rat. Reproductive Toxicology 22 37-43. (https://doi. org/10.1016/j.reprotox.2005.11.001)

Jiang YF, Tsui KH, Wang PH, Lin CW, Wang JY, Hsu MC, Chen YC \& Chiu CH 2011 Hypoxia regulates cell proliferation and steroidogenesis through protein kinase A signaling in bovine corpus luteum. Animal Reproduction Science 129 152-161. (https://doi. org/10.1016/j.anireprosci.2011.12.004)

Klöting N, Kovacs P, Kern M, Heiker JT, Fasshauer M, Schön MR, Stumvoll M, Beck-Sickinger AG \& Blüher M 2011 Central vaspin administration acutely reduces food intake and has sustained blood glucose-lowering effects. Diabetologia 54 1819-1823. (https://doi. org/10.1007/s00125-011-2137-1)

Kumar L, Panda RP, Hyder I, Yadav VP, Sastry KV, Sharma GT, Mahapatra RK, Bag S, Bhure SK, Das GK, et al. 2012 Expression of leptin and its receptor in corpus luteum during estrous cycle in buffalo (Bubalus bubalis). Animal Reproduction Science 135 8-17. (https://doi.org/10.1016/j.anireprosci.2012.08.030)

Kurowska P, Mlyczyńska E, Barbe A, Staub C, Gregoraszczuk E, Dupont J \& Rak A 2019a Vaspin in the pig ovarian follicles: expression and regulation by different hormones. Reproduction 158 135-146. (https:// doi.org/10.1530/REP-19-0034)

Kurowska P, Mlyczyńska E, Dawid M, Opydo-Chanek M, Dupont J \& Rak A $2019 b$ In vitro effects of vaspin on porcine granulosa cell proliferation, cell cycle progression, and apoptosis by activation of GRP78 receptor and several kinase signaling pathways including MAP3/1, AKT, and STAT3. International Journal of Molecular Sciences 20 5816. (https://doi.org/10.3390/ijms20225816)

Kurowska P, Mlyczyńska E, Dawid M, Dupont J \& Rak A 2020 Role of vaspin in porcine ovary: effect on signaling pathways and steroid synthesis via GRP78 receptor and protein kinase A. Biology of Reproduction 102 1290-1305. (https://doi.org/10.1093/biolre/ioaa027)

Kurzynska A, Chojnowska K, Bogacki M \& Bogacka I 2016 PPAR ligand association with prostaglandin F2 $\alpha$ and E2 synthesis in the pig corpus luteum-an in vitro study. Animal Reproduction Science 172 157-163. (https://doi.org/10.1016/j.anireprosci.2016.07.014)

Lai X, Zhang C, Wang J, Wang C, Lan X, Zhang C, Lei C \& Chen H 2013 mRNA expression pattern and association study with growth traits of bovine vaspin gene. Molecular Biology Reports 40 4499-4505. (https:// doi.org/10.1007/s11033-013-2542-2

Lappas M, Permezel M \& Rice GE 2005 Leptin and adiponectin stimulate the release of proinflammatory cytokines and prostaglandins from human placenta and maternal adipose tissue via nuclear factorkappaB, peroxisomal proliferator-activated receptor-gamma and extracellularly regulated kinase 1/2. Endocrinology 146 3334-3342. (https://doi.org/10.1210/en.2005-0406)

Li Q, Chen R, Moriya J, Yamakawa J, Sumino H, Kanda T \& Takahashi T 2008 A novel adipocytokine, visceral adipose tissue-derived serine protease inhibitor (vaspin), and obesity. Journal of International Medical Research 36 625-629. (https://doi org/10.1177/147323000803600402)

Maleszka A, Smolinska N, Nitkiewicz A, Kiezun M, Chojnowska K, Dobrzyn K, Szwaczek H \& Kaminski T 2014 Adiponectin expression in the porcine ovary during the oestrous cycle and its effect on ovarian steroidogenesis. International Journal of Endocrinology 2014957076. (https://doi.org/10.1155/2014/957076)

Mesen TB \& Young SL 2015 Progesterone and the luteal phase: a requisite to reproduction. Obstetrics and Gynecology Clinics of North America $\mathbf{4 2}$ 135-151. (https://doi.org/10.1016/j.ogc.2014.10.003)

Mierzyński R, Poniedziałek-Czajkowska E, Dłuski D, Patro-Małysza J, Kimber-Trojnar Ż, Majsterek M \& Leszczyńska-Gorzelak B 2019 Nesfatin-1 and vaspin as potential novel biomarkers for the prediction and early diagnosis of gestational diabetes mellitus. International Journal of Molecular Sciences 20 159. (https://doi. org/10.3390/ijms20010159)

Nakatsuka A, Wada J, Iseda I, Teshigawara S, Higashio K, Murakami K, Kanzaki M, Inoue K, Terami T, Katayama A, et al. 2013 Visceral adipose tissue-derived serine proteinase inhibitor inhibits apoptosis of endothelial cells as a ligand for the cell-surface GRP78/voltagedependent anion channel complex. Circulation Research 112 771-780. (https://doi.org/10.1161/CIRCRESAHA.111.300049)

Park HJ, Park JY, Kim JW, Yang SG, Jung JM, Kim MJ, Park JJ \& Koo DB 2017 Regulation of the endoplasmic reticulum stress by BIP/ GRP78 is involved in meiotic maturation of porcine oocytes in vitro. Development and Reproduction 21 407-415. (https://doi.org/10.12717/ DR.2017.21.4.407) https://joe.bioscientifica.com https://doi.org/10.1530/JOE-20-0332 (c) 2020 Society for Endocrinology Published by Bioscientifica Ltd. Printed in Great Britain 
Przygrodzka E, Kaczmarek MM, Kaczynski P \& Ziecik AJ 2016 Steroid hormones, prostanoids, and angiogenic systems during rescue of the corpus luteum in pigs. Reproduction 151 135-147. (https://doi org/10.1530/REP-15-0332)

Rak A, Drwal E, Wróbel A \& Gregoraszczuk EŁ 2015 Resistin is a survival factor for porcine ovarian follicular cells. Reproduction $150343-355$. (https://doi.org/10.1530/REP-15-0255)

Rak A, Drwal E, Rame C, Knapczyk-Stwora K, Słomczyńska M, Dupont J \& Gregoraszczuk EL 2017 Expression of apelin and apelin receptor (APJ) in porcine ovarian follicles and in vitro effect of apelin on steroidogenesis and proliferation through APJ activation and different signaling pathways. Theriogenology 96 126-135. (https://doi org/10.1016/j.theriogenology.2017.04.014)

Reverchon M, Bertoldo MJ, Ramé C, Froment P \& Dupont J 2014 Chemerin (RARRES2) decreases in vitro granulosa cell steroidogenesis and blocks oocyte meiotic progression in bovine species. Biology of Reproduction 90 102. (https://doi.org/10.1095/biolreprod.113.117044)

Różycka M, Kurowska P, Grzesiak M, Kotula-Balak M, Tworzydło W, Rame C, Gregoraszczuk E, Dupont J \& Rak A 2018 Apelin and apelin receptor at different stages of corpus luteum development and effect of apelin on progesterone secretion and $3 \beta$-hydroxysteroid

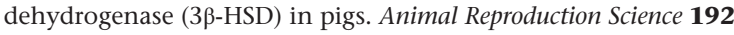
251-260. (https://doi.org/10.1016/j.anireprosci.2018.03.021)

Rytelewska E, Kisielewska K, Kiezun M, Dobrzyn K, Gudelska M, Rak A, Dupont J, Kaminska B, Kaminski T \& Smolinska N 2020 Expression of chemerin and its receptors in the ovaries of prepubertal and mature gilts. Molecular Reproduction and Development 87 739-762. (https://doi. org/10.1002/mrd.23391)

Shirasuna K, Shimizu T, Sayama K, Asahi T, Sasaki M, Berisha B, Schams D \& Miyamoto A 2008 Expression and localization of apelin and its receptor APJ in the bovine corpus luteum during the estrous cycle and prostaglandin F2alpha-induced luteolysis. Reproduction 135 519-525. (https://doi.org/10.1530/REP-07-0409)

Siawrys G \& Smolinska N 2013 In vitro effects of luteinizing hormone, progesterone and oestradiol-17 $\beta$ on leptin gene expression and leptin secretion by porcine luteal cells obtained in early pregnancy. Journal of Physiology and Pharmacology 64 513-520.

Sirotkin AV, Rafay J \& Kotwica J 2009 Leptin controls rabbit ovarian function in vivo and in vitro: possible interrelationships with ghrelin. Theriogenology 72 765-772. (https://doi.org/10.1016/j. theriogenology.2009.05.011)

Stocco C, Telleria C \& Gibori G 2007 The molecular control of corpus luteum formation, function, and regression. Endocrine Reviews $\mathbf{2 8}$ 117-149. (https://doi.org/10.1210/er.2006-0022)

Stouffer R \& Hennebold J 2015 Structure, function, and regulation of the corpus luteum. In Knobil and Neill's Physiology of Reproduction, 4th ed., pp. 1023-1076. Eds T Plant \& A Zeleznik. Amsterdam, Netherlands: Elsevier Inc.

Tan BK, Heutling D, Chen J, Farhatullah S, Adya R, Keay SD, Kennedy CR, Lehnert H \& Randeva HS 2008 Metformin decreases the adipokine vaspin in overweight women with polycystic ovary syndrome concomitant with improvement in insulin sensitivity and a decrease in insulin resistance. Diabetes 57 1501-1507. (https://doi. org/10.2337/db08-0127)

Vandesompele J, De Preter K, Pattyn F, Poppe B, Van Roy N, De Paepe A \& Speleman F 2002 Accurate normalization of real-time quantitative RT-PCR data by geometric averaging of multiple internal control genes. Genome Biology 3 RESEARCH0034. (https://doi.org/10.1186/ gb-2002-3-7-research0034)

von Loeffelholz C, Möhlig M, Arafat AM, Isken F, Spranger J, Mai K, Randeva HS, Pfeiffer AF \& Weickert MO 2010 Circulating vaspin is unrelated to insulin sensitivity in a cohort of nondiabetic humans. European Journal of Endocrinology 162 507-513. (https://doi. org/10.1530/EJE-09-0737)

Waclawik A 2011 Novel insights into the mechanisms of pregnancy establishment: regulation of prostaglandin synthesis and signaling in the pig. Reproduction 142 389-399. (https://doi.org/10.1530/REP-11-0033)

Ziecik AJ, Przygrodzka E, Jalali BM \& Kaczmarek MM 2018 Regulation of the porcine corpus luteum during pregnancy. Reproduction 156 R57-R67. (https://doi.org/10.1530/REP-17-0662)

Received in final form 12 September 2020

Accepted 22 September 2020

Accepted Manuscript published online 23 September 2020 (c) 2020 Society for Endocrinology Published by Bioscientifica Ltd. Printed in Great Britain 